\title{
Pengembangan Media Pembelajaran Bangun Ruang Berbasis Discovery Learning dengan Construct 2 dalam Meningkatkan Kemampuan Pemecahan Masalah Matematika
}

\author{
Atik Herawati $^{1 *}$, Wahyudi $^{2}$, Endang Indarini ${ }^{3}$ \\ 1,2,3 Jurusan Pendidikan Guru Sekolah Dasar (PGSD), FKIP Universitas Kristen Satya Wacana, Indonesia.
}

\author{
A R T I C L E I N F O \\ Article history: \\ Received 19 August 2018 \\ Received in revised form \\ 09 September 2018 \\ Accepted 18 October 2018 \\ Available online 28 \\ November 2018

\section{Kata Kunci:} \\ Discovery Learning, \\ Pemecahan masalah, \\ Aplikasi game \\ Keywords: \\ Discovery Learning, \\ Problem solving, Game \\ application
}

\begin{abstract}
A B S T R A K
Penelitian ini memiliki tujuan untuk mengetahui media pembelajaran bangun ruang yang dikembangkan valid, praktis, dan efektif untuk pembelajaran. Penelitian ini termasuk penelitian pengembangan media pembelajaran berdasarkan metode Discovery Learning dengan construct 2 dalam meningkatkan kemampuan pemecahan masalah matematika untuk siswa kelas V SD. Hasil penelitian ini memperoleh data evaluasi aplikasi game ahli media 67,6\% dinyatakan Cukup Layak, uji ahli materi 87,2\% dinyatakan Layak. Kepraktisan diperoleh dari evaluasi ahli desain pembelajaran (guru) 92,8\% dinyatakan Layak dan respon siswa 95\% dinyatakan Layak. Keefektifan aplikasi yang diperoleh dari ketuntasan pre-test dan posttest yaitu Sig. (2-tailed) sama dengan 0.000 atau kurang dari 0.50 dinyatakan terdapat perbedaan yang signifikan antara hasil pre-test dan post-test.
\end{abstract}

\section{A B S T R A C T}

This study aims to find out the space learning media that are developed valid, practical, and effective for learning. This study includes the development of learning media research based on the Discovery Learning method with construct 2 in improving mathematical problem solving skills for fifth grade elementary school students. The results of this study obtained data evaluation application game media expert $67.6 \%$ declared Fairly Eligible, material expert test $87.2 \%$ was declared Eligible. Practicality is obtained from the evaluation of learning design experts (teachers) $92.8 \%$ stated Eligible and the response of $95 \%$ students declared Eligible. The effectiveness of the application obtained from the completeness of the pre-test and post-test, namely Sig. (2-tailed) equal to 0,000 or less than 0.50 stated that there are significant differences between the results of the pre-test and post-test. 


\section{Pendahuluan}

Pendidikan menurut Elfachmi (2016:67) merupakan usaha sadar yang terencana untuk mewujudkan suasana belajar serta proses pembelajaran supaya siswa secara aktif mengembangkan potensinya untuk memiliki kekuatan spiritual, keagamaan, pengendalian diri, kepribadian, kecerdasan, akhlak yang mulia serta keterampilan yang dibutuhkan baik untuk dirinya sendiri mapun masyarakat. Pendidikan di Indonesia mengalami perkembangan pesat dalam penggunaan teknologi dan informasi sebagai sarana untuk menyampaikan pembelajaran. Pemanfaatan teknologi yang berkaitan dengan media pembelajaran yang dipadukan dengan metode pembelajaran yang tepat mampu memudahkan tercapainya tujuan pembelajaran serta dapat meningkatkan kemampuan siswa. Pembelajaran menurut Komalasari (2010:3) merupakan suatu sistem memberikan pengajaran kepada siswa yang direncanakan, dilaksanakan, kemudian dilakukan evaluasi secara sistematis agar siswa mampu mencapai tujuan pembelajaran secara efektif dan efisien. Media pembelajaran menurut Rusman (2013:161) merupakan sarana atau wahana yang dipergunakan untuk menyampaikan informasi maupun pesan dari sumber pesan kepada penerima. Sedangkan media pembelajaran menurut Musfiqon (2012:28) merupakan sebagai alat bantu fisik maupun alat bantu non fisik yang digunakan sebagai perantara guru dan siswa supaya pemahaman pembelajaran lebih efektif dan efisien. Dunia pendidikan memiliki sarana dan prasarana yang memadai dengan media pembelajaran yang mendukung serta alat peraga yang bervariasi sesuai kegunaan, namun teknologi informasi terus berkembang pesat seiring dengan bertumbuhnya pendidikan di Indonesia. Berdasarkan pemaparan teori, pembelajaran dan media pembelajaran sangat terkait dan menjadi saling mendukung dalam proses pelaksanaannya, sehingga pembelajaran membutuhkan media pembelajaran dan tanpa pembelajaran maka media pembelajaran tidak dapat dipergunakan.

Penggunaan perangkat lunak sebagai penunjang untuk meningkatkan tingkat perhatian dan motivasi siswa pada pembelajaran. Software Construct 2 (Hartanto, 2014) merupakan salah satu perangkat lunak yang dapat menghasilkan aplikasi atau game (game engine), pemilihan software Construct 2 memiliki alasan karena mudah memahami sebuah materi jika disampaikan dengan menarik dan unik serta tidak memerlukan pemprograman yang rumit untuk membuatnya. Aplikasi game yang akan dirancang memuat materi mata pelajaran matematika untuk kelas $\mathrm{V}$ sekolah dasar.

Hakekat belajar matematika merupakan sebuah proses atau aktivitas berfikir disertai dengan aktivitas sikap dan fisik (H. Erman, 2003). Kesalahan merupakan bagian dari sebuah proses, sehingga guru harus membuka kesempatan bagi siswa untuk menjawab sesuai dengan apa yang diketahuinya. Pembelajaran matematika memerlukan kemandirian belajar, hal ini sesuai dengan hakekat matematika menurut Huri (2011) kebenarannya berdasarkan logika, objek bersifat abstrak, melatih kemampuan berhitung dan berpikir secara logis dan aplikatif. Penelitian ini mengupas materi bangun ruang untuk siswa kelas V SD materi ini mampu menggugah eksplorasi siswa dalam mengembangkan rasa ingin tahunya dengan mencari informasi dari berbagai sumber walaupun sudah terdapat alat peraga yang disediakan, selain itu tatanan bahasa pada media disesuaikan dengan tingkat pemahaman siswa sekolah dasar. Huri (2011) menyimpulkan bahwa hasil belajar merupakan puncak kegiatan belajar yang dapat diukur atau diamati berupa suatu perubahan baik dalam aspek pengetahuan (kognitif), aspek sikap (afektif), dan aspek keterampilan (psikomotor).

Pengertian media pembelajaran tersebut sejalan dengan sintaks metode Discovery Learning, menurut Bruner (Direktorat Pembinaan Sekolah Dasar, 2016:58) Discovery Learning can be defined as the learning that takes place when the student is not presented with subject matter in the final form, but rather is required to organize it him self, atau dapat diartikan siswa menemukan informasi sendiri tanpa harus menyajikan materi dalam bentuk final atau akhir, sehingga siswa dapat menemukan informasi sesuai dengan pemahamannya sendiri. Penelitian ini memiliki tujuan sesuai dengan pendapat Bruner, siswa perlu bertindak aktif untuk mendapatkan pemahamannya sendiri. Pemecahan masalah menurut Wahyudi (2017:16) merupakan suatu usaha untuk menemukan jalan keluar dari sebuah kesulitan atau masalah tidak rutin sehingga masalah tersebut tidak menjadi masalah lagi. Pemecahan masalah menurut George Polya (1985 dalam Wahyudi 2017:18) memiliki empat aspek, diantaranya; (1) Pemahamana Masalah (understanding the problem); (2) Perencanaan penyelesaian (devising a plan); (3) Melaksanakan perencanaan (carring out of the plan); dan (4) Pemeriksaan kembali proses dan hasil (looking back) .

Penelitian pengembangan menurut Sugiyono (2011:407) merupakan metode penelitian yang digunakan untuk menghasilkan produk dan menguji produk tertentu. Penelitian ini menggunakan langkah-langkah pengembangan Sugiyono (2011:409) yaitu: (a)Potensi dan Masalah; (b) Pengumpulan data; (c) Desain Produk; (d) Validasi Desain; (e) Revisi Desain; (f) Ujicoba produk; (g) Revisi Produk; (h) Ujicoba pemakaian; (i) Revisi produk; dan (j) Produksi masal. Produk akhir yang dihasilkan penelitian pengembangan ini berupa media pembelajaran aplikasi game dengan software Construct 2 sesuai sintaks 
metode Discovery Learning untuk meningkatkan kemampuan pemecahan masalah matematika siswa kelas V.

\section{Metode}

Penelitian ini merupakan penelitian pengembangan atau research and development. Borg and Gall (dalam Sukmadinata 2012: 169) mendefinisikan bahwa penelitian pengembangan merupakan penelitian yang dilakukan untuk menyempurnakan produk yang telah ada atau menghasilkan produk baru. Penelitian ini menghasilkan produk berupa media pembelajaran dalam bentuk aplikasi game bangun ruang. Penelitian ini menggunakan langkah-langkah pengembangan Sugiyono dengan melaksanakan enam langkah pengembangan sesuai kebutuhan peneliti, diantaranya; (1) Potensi dan Masalah; (2) Pengumpulan Data; (3) Desain Produk; (4) Validasi Desain; (5) Revisi Desain; dan (6) Ujicoba Produk. Langkah pengembangan Sugiyono dipilih karena langkah pada pengembangan ini urutan langkah mudah dipahami. Hasil akhir pada setiap langkah merupakan produk awal untuk langkah selanjutnya.

Penelitian pengembangan ini dilaksanakan di SD Negeri Gendongan 02 yang terletak di wilayah Kecamatan Tingkir, Kota Salatiga. Data yang diperoleh dari lapang. Data yang telah diperoleh dari penelitian dikumpulkan melalui wawancara, angket ahli atau pakar, observasi, dan tes. Wawancara dilakukan kepada guru pengampu mata pelajaran matematika sekaligus wali kelas V SD Negeri Gendongan 02 untuk mengetahui potensi dan permasalahan yang ada di lingkungan sekolah serta memperoleh informasi sebelum melakukan penelitian, serta dilakukan kepada siswa kelas V SD Negeri Gendongan 02 terkait dengan pembelajaran dalam kelas. Angket untuk ahli atau pakar yaitu ahli media, ahli materi, dan ahli desain pembelajaran untuk mengetahui kelayakan penggunaan media pembelajaran untuk proses pembelajaran. Angket untuk respon siswa berupa angket tertutup untuk mengethaui respon siswa saat menggunakan media pembelajaran aplikasi game. Observasi dilakukan terhadap guru dan siswa pada saat proses pembelajaran berlangsung. Tes berupa pre-test dan post-test digunakan untuk mengukur peningkatakan kemampuan siswa.

Langkah yang digunakan untuk mengumpulkan data yaitu menyusun instrumen berdasarkan kisikisi, melakukan uji validitas dan reliabilitas dengan menggunakan software SPSS 22.0 for windows, memberikan pre-test, melaksanakan penelitian, memberikan post-test, dan menganalisis data yang telah diperoleh setelah melaksanakan penelitian.

Data hasil uji evaluasi oleh pakar sebagai validasi produk dianalisis dengan menggunakan rating scale. Analisis awal data skor yang diperoleh dari hasil angket tertutup untuk para ahli dijumlahkan dan dirata-rata untuk angket masing-masing ahli, kemudian skor tersebut dihitung dengan menggunakan rumus:

$$
P=\frac{\text { jumlah skor hasil pengumpulan data }}{\text { jumlah skor kriterium }} \times 100 \%
$$

Keterangan :

$\mathrm{P}=$ Persentase Kelayakan Media

Skor kriterium = skor maks. tiap butir $\mathrm{x}$ jumlah butir soal $\mathrm{x}$ jumlah responden

Angka persentase yang didapat selanjutnya diinterpretasikan dalam Tabel 1. berikut:

Tabel 1. Skala Interpretasi dengan rating scale

\begin{tabular}{cc}
\hline Skor persentase (\%) & Interpretasi \\
\hline $0 \leq$ skor $\leq 25$ & Tidak layak \\
$25<$ skor $\leq 50$ & Kurang layak \\
$50<$ skor $\leq 75$ & Cukup layak \\
$75<$ skor $\leq 100$ & Layak \\
\hline
\end{tabular}

Berdasarkan skala interpretasi di atas, maka media pembelajaran berupa aplikasi game dapat dinyatakan layak untuk diujicobakan apabila memiliki rentang skor persentase minimal 75 atau maksimal 100. Kepraktisan media aplikasi game diperoleh dengan data hasil respon siswa dan ahli desain pembelajaran (guru) saat ujicoba produk. Data uji efektivitas media pembelajaran diperoleh dari hasil pre-test dan post-test, skor akhir kemudian di uji dengan Paired Samples T Test dengan software SPSS 22 for windows. 


\section{Hasil dan Pembahasan}

Pada Pengembangan media pembelajaran aplikasi game berdasarkan langkah-langkah Sugiyono yang telah dilaksanakan sebagai berikut:

Potensi dan masalah, berdasarkan hasil wawancara dengan guru pengampu mata pelajaran matematika dan salah satu siswa kelas V, pembelajaran matematika di kelas umumnya hanya sebatas menjelaskan materi sesuai dengan program tahunan (prota) dan program semester (promes) yang telah dibuat pada awal tahun ajar. Respon siswa saat menerima pelajaran lebih pasif karena hanya mendengarkan penjelasan materi dan mengerjakan soal pada buku, selain itu penggunaan sarana berupa media yang disediakan di sekolah hanya difungsikan sesekali. Hasil kemampuan siswa menurut guru masih kurang dan lemah, hanya beberapa siswa yang memperoleh nilai melampaui KKM untuk mata pelajaran matematika.

Pengumpulan data, tahap ini dimulai dengan mencari sebanyak mungkin sumber yang dapat dijadikan sebagai referensi, kemudian melaksanakan langkah mengembangakan media sebagai bahan ajar menurut Rusman (2012: 171) yaitu; (1) mengidentifikasi kebutuhan serta karakteristik siswa sesuai hasil wawancara guru dan siswa; (2) membuat rencana pelaksanaan pembelajaran (RPP) dengan langkah memilih KD dan membuat indikator, merumuskan tujuan pembelajaran, merumuskan materi yang dikembangkan, memilih metode pembelajaran, memilih media pembelajaran dan memilih alat ukur.

Desain produk, pada tahap ini perancangan dan pembuatan produk aplikasi game mulai dilakukan. Software Construct 2 dipilih karena pengoperasiannya mudah untuk digunakan siswa. Langkah pertama yaitu membuat story board untuk menjelaskan garis besar aplikasi game yang diinginkan dengan runtut, halaman awal aplikasi game disajikan kolom identitas pengguna, scene selanjutnya berisi judul dan pilihan menu utama serta pengaturan suara, scene info game berisi muatan kompetensi pada game dan informasi pihak terkait dalam aplikasi game, scene pilihan menu game terdiri atas game, materi, dan quiz.

Langkah kedua adalah implementasi dari pembuatan story board, dalam pembuatan aplikasi game dengan pihak ahli komputer yang lebih kompeten di bidang aplikasi dengan menggunakan Construct 2.

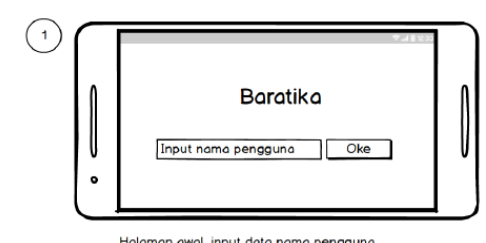

Holaman owal, input data nama pengguno

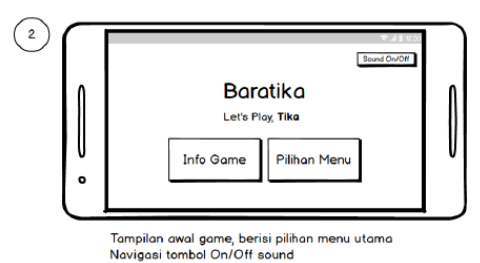

Tampilan awal game, berisi pilihan menu utam
Novigosi tombol On/off sound

Gambar 1 story board halaman awal game dan menu utama
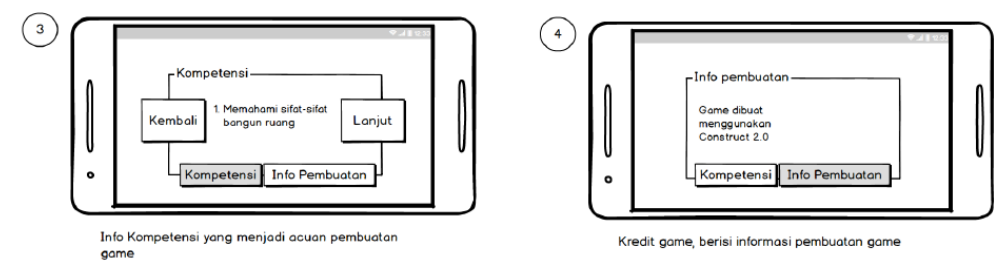

Gambar 2 story board info game

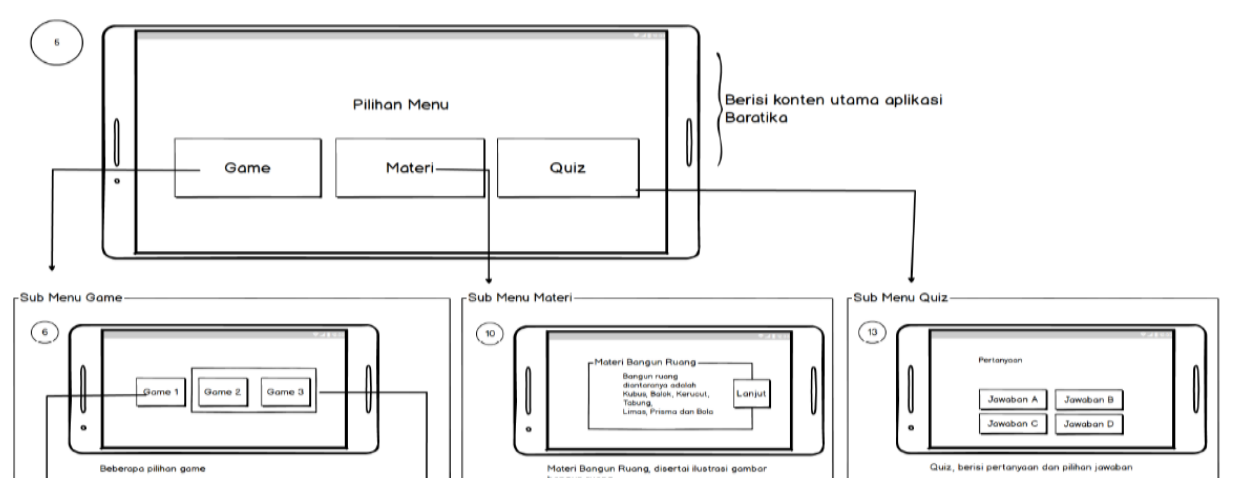

Gambar 3 story board pada pilihan menu game 
Validasi desain, berdasarkan hasil evaluasi ahli media yang telah di olah menunjukkan persentase sebesar $67,6 \%$ pada rerata $50<$ skor $\leq 75$ interpretasi cukup layak. Hasil evaluasi ahli materi menunjukkan persentase $87,2 \%$ dengan rerata $75 \leqslant$ skor $\leq 100$ interpretasi layak. Sedangkan hasil evaluasi oleh desain pembelajaran menunjukkan persentase $92,8 \%$ dengan rerata $75<$ skor $\leq 100$ interpretasi layak.

Revisi desain, tahap revisi dilakukan setelah evaluasi dan validasi oleh ahli atau pakar, kemudian bagian yang menuai komentar maupun saran diperbaiki untuk kemudian siap ujicoba di sekolah.

Tabel 2. Revisi berdasarkan saran ahli

\begin{tabular}{|c|c|}
\hline Saran & Tampilan sebelum revisi \\
\hline $\begin{array}{lr}\text { Petunjuk } & \text { umum } \\
\text { penggunaan } & \text { aplikasi } \\
\text { belum } & \text { ada. } \\
\text { tambahkan } & \text { petunjuk } \\
\text { umum penggunaan } \\
\text { media di menu "Info } \\
\text { Game" }\end{array}$ & 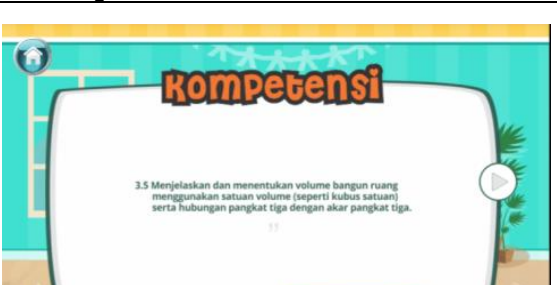 \\
\hline
\end{tabular}

\section{Tampilan setelah revisi}

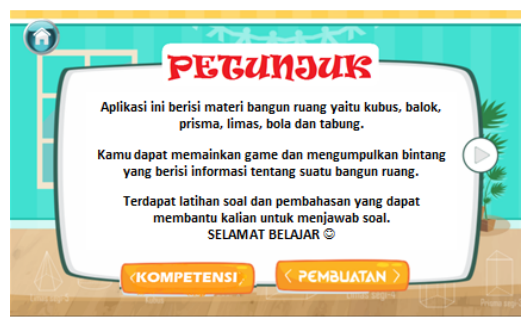

Kalimat pada menu "Kompetensi" dan "Tujuan" adalah untuk guru. Sedangkan bagi siswa kelas 5 SD terlalu tinggi, sehingga bisa diganti dengan kalimat yang lebih sederhana.

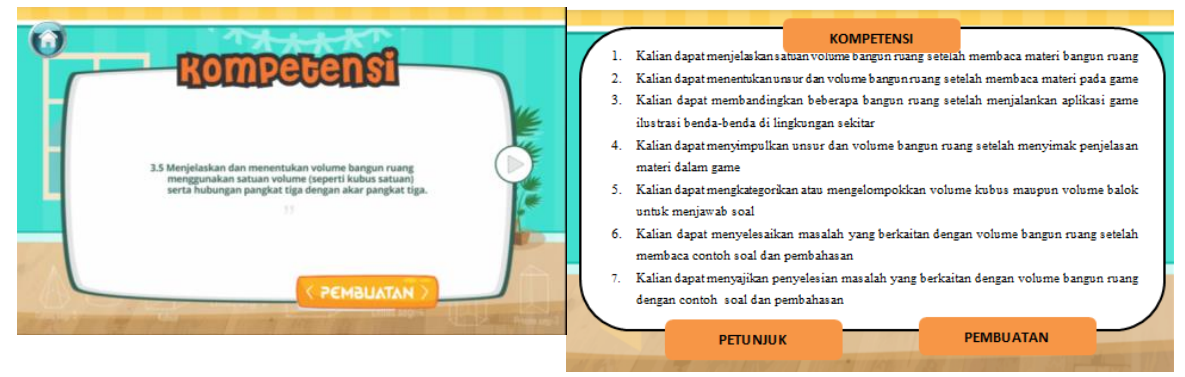

Sebaiknya diberi visualisasi di setiap penjelasan materi. Misal pada sifat-sifat kubus: memiliki 12 buah rusuk, maka ditampilkan gambar kubus dan rusukrusuknya diberi warna yang menonjol/tebal.

Sehingga siswa dapat melihat rusuk-rusuk tersebut.

\section{Saran}

Sebenarnya frame didalam aplikasi sudah teratur dan konsisten, tetapi ukuran huruf terkorbankan menjadi kecil. Sebaiknya frame untuk tempat tulisan diperbesar agar tulisan bisa lebih

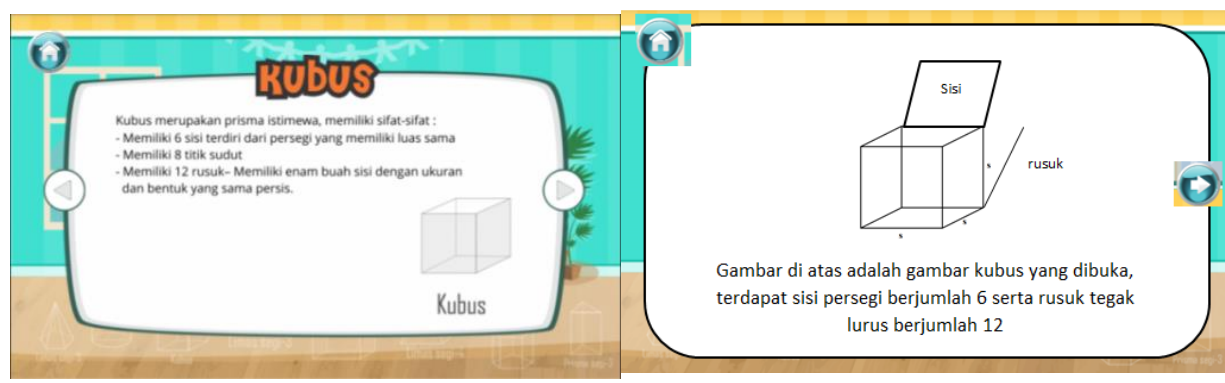
optimal.
Tampilan sebelum revisi

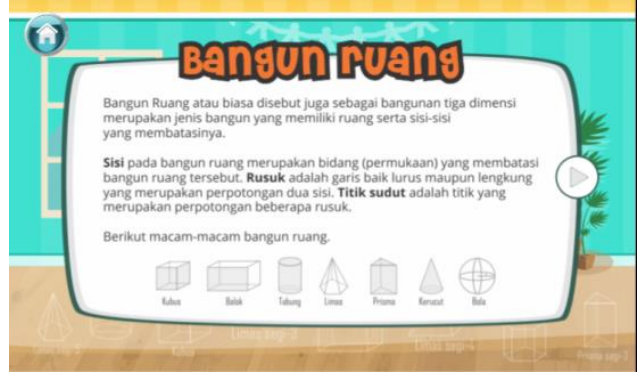

Tampilan setelah revisi

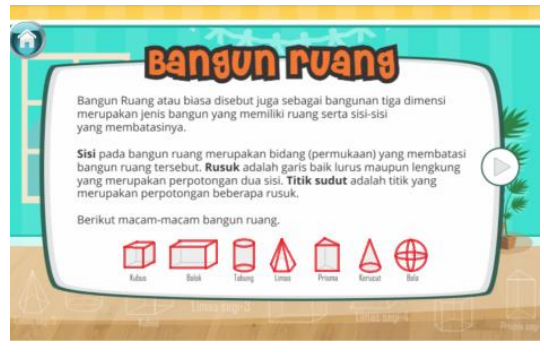




\begin{tabular}{|c|c|}
\hline Saran & Tampilan sebelum revisi \\
\hline $\begin{array}{l}\text { Tombol navigasi } \\
\text { seperti BACK dan } \\
\text { HOME belum lengkap } \\
\text { pada beberapa scene. } \\
\text { Sehingga pada } \\
\text { beberapa scene harus } \\
\text { keluar dari aplikasi } \\
\text { dulu untuk masuk ke } \\
\text { menu sebelumnya } \\
\text { ataupun menu utama. }\end{array}$ & $\begin{array}{c}\text { Scene "Quiz" memang tidak diberi tombol navigasi untuk "back" atau "home", } \\
\text { dengan tujuan supaya membuat pengguna fokus mengerjakan soal pada Quiz } \\
\text { tanpa melihat materi yang telah dipelajari dan mengingat cara untuk } \\
\text { mengerjakan soal dengan tepat. }\end{array}$ \\
\hline
\end{tabular}

Ujicoba produk, setelah melalui revisi kemudian dilakukan ujicoba di kelas V SD Negeri Gendongan 02 pada pembelajaran dengan media aplikasi game.Selama proses pembelajaran, dilaksanakan pengumpulan data presentasi, setelah pembelajaran disebarkan angket kepada 10 siswa sebagai responden untuk mengetahui minat siswa terhadap aplikasi game serta untuk mengetahui tingkat kepraktisan aplikasi game.

Data observasi yang dilakukan oleh guru saat proses pembelajaran dengan bantuan aplikasi game berlangsung merupakan data keterlaksanaan RPP dengan implementasinya di kelas. Berdasarkan data observasi guru dapat diketahui apakah aplikasi game sesuai sintaks metode Discovery Learning untuk meningkatkan kemampuan dengan aspek pemecahan masalah matematika sesuai atau tidak. Hasil observasi guru menunjukkan persentase keterlaksanaan langkah dalam RPP sebesar 86,7\% atau sama dengan 26 langkah yang terlaksana, sementara langkah yang tidak terlaksana sebesar $13,3 \%$ atau 4 langkah. Data hasil respon siswa dengan 10 responden, setelah di rata-rata memperoleh persentase 95\% dengan rerata rating scale $75<$ skor $\leq 100$ sehingga memperoleh interpretasi layak.

Hasil pre-test dan post-test terhadap aspek kemampuan pemecahan masalah untuk ketercapaian kompetensi dasar 3(kognitif) memiliki rata-rata berurutan sebesar 54,57\% dan 83,3\%. Penilaian presentasi untuk ketercapaian kompetensi dasar 4 (psikomotor) disajikan dalam diagram berikut:

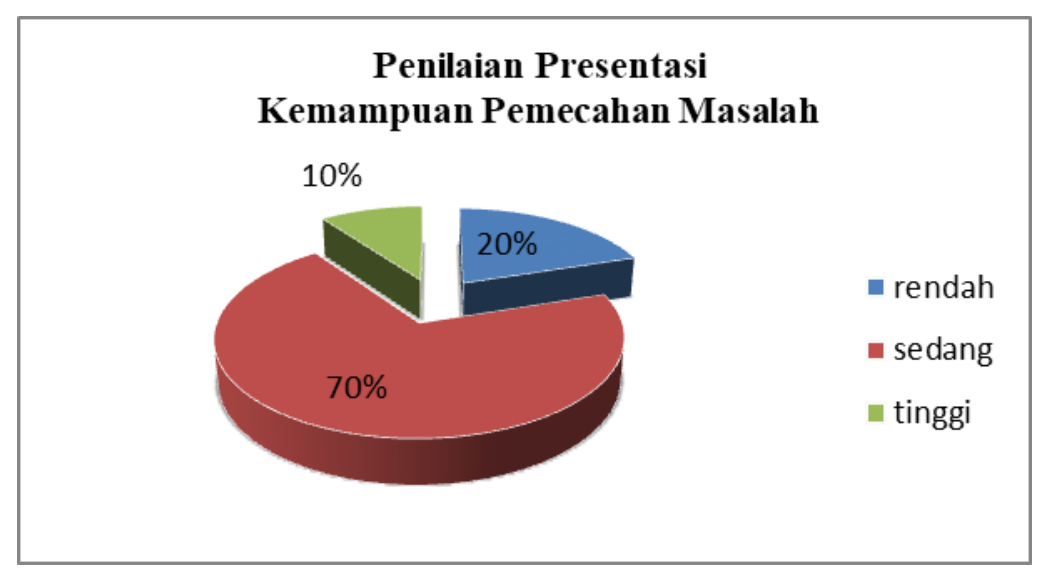

Gambar 4 Diagram Lingkaran hasil penilaian presentasi kemampuan pemecahan masalah

Efektivitas penggunaan media pembelajaran diketahui melalui uji paired sample $t$ test terhadap terdapat hasil pre-test dan hasil post-test dengan hasil Sig. (2-tailed) 0.000 atau kurang dari 0.05 dinyatakan terdapat perbedaan yang signifikan, disajikan dalam Tabel berikut:

Tabel 3. Hasil Uji Paired Samples T Test

Paired Samples Test

\begin{tabular}{|c|c|c|c|c|c|c|c|c|}
\hline & \multicolumn{5}{|c|}{ Paired Differences } & \multirow[b]{3}{*}{$t$} & \multirow[b]{3}{*}{ df } & \multirow[b]{3}{*}{ Sig. (2-tailed) } \\
\hline & \multirow[b]{2}{*}{ Mean } & \multirow[b]{2}{*}{ Std. Deviation } & \multirow{2}{*}{$\begin{array}{l}\text { Std. Error } \\
\text { Mean }\end{array}$} & \multicolumn{2}{|c|}{$\begin{array}{l}\text { 95\% Confidence Interval of the } \\
\text { Difference }\end{array}$} & & & \\
\hline & & & & Lower & Upper & & & \\
\hline Pair 1 PRE_TEST - POST_TEST & -42.350 & 6.556 & 1.466 & -45.418 & -39.282 & -28.890 & 19 & .000 \\
\hline
\end{tabular}




\section{Simpulan dan Saran}

Berdasarkan penelitian ini dapat ditarik kesimpulan bahwa tingkat validitas produk berupa aplikasi game berbasis Discovery Learning dengan software Construct 2 dinyatakan Layak untuk digunakan, karena memperoleh data hasil evaluasi ahli media $67,6 \%$ serta hasil evaluasi ahli atau pakar materi $87,2 \%$. Kepraktisan penggunaan media pembelajaran aplikasi game terbukti dengan adanya data evaluasi ahli desain pembelajaran $92,8 \%$ serta data rata-rata respon siswa dengan 10 responden $95 \%$. Media pembelajaran dinyatakan efektif dengan data yang menyatakan terdapat perbedaan yang signifikan antara hasil pre-test dan hasil post-test dengan acuan paired sample t test dengan hasil Sig. (2-tailed) 0.000 atau kurang dari 0.05 .

\section{Daftar Rujukan}

Adiwijaya, M., \& Christyono, Y. (2015). Perancangan game edukasi platform belajar matematika Berbasis android menggunakan construct 2. TRANSIENT, 4(1), 128-133.

Budiningsih, A. (2005). Model Discovery Learning. Jakarta: Pustaka Mandiri.

Darmanto, B., \& Sudarmilah, E. (2016). Game Edukasi Dampak Pergaulan Bebas. PROtek, 3(2), 51-56.

Dasar, D. P. (2016). Panduan Teknis Pembelajaran dan Penilaian di Sekolah Dasar. Jakarta: Kementrian Pendidikan dan Kebudayaan.

Direktorat Pembinaan Sekolah Dasar. (2016). Panduan Teknis Pembelajaran dan Penilaian di Sekolah Dasar. Jakarta: Kementrian Pendidikan dan Kebudayaan.

Elfachmi, A. K. (2016). Pengantar Pendidikan. Jakarta: Penerbit Erlangga.

Hartanto, A. D., Dhuhita, W. M. P., \& Tinangon, A. (2014). Perancangan game multi platform menggunakan scirra construct 2 dan html 5. Prosiding Simposium Nasional RAPI XIII-2014 FT UMS.

Jati Nugroho, S. (2015). Aplikasi Pembelajaran Bahasa Inggris Untuk Anak SD Menggunakan Construct 2 (Doctoral dissertation, Universitas Muhammadiyah Surakarta).

Komalasari, K. (2010). Pembelajaran Kontekstual Konsep dan Aplikasi. Bandung: PT Refika Aditama.

Musfiqon, H. (2012). Pengembangan Media \& Sumber Pembelajaran. Jakarta: PT Prestasi Pustaka.

Prasetyo, Y. D. (2012). Pengembangan Mobile Game "Brainchemist" Sebagai Media Pembelajaran Kimia SMA/MA pada Materi Asam Basa, Larutan Penyangga, dan Hidrolisis Garam (Doctoral dissertation, Fakultas Matematika dan Ilmu Pengetahuan Alam).

Putriani, D., \& Waryanto, N. H. (2017). Pengembangan Media Pembelajaran Berbasis Android Dengan Program Construct 2 Pada Materi Bangun Ruang Sisi Datar Untuk Siswa SMP Kelas 8. Jurnal Pendidikan Matematika-S1, 6(4), 1-10.

Rahmah, M. (2013). Pengembangan Instrumen Penilaian Kualitas Media Pembelajaran Elektronik Kimia dalam Bentuk Penilaian Skala. Yogyakarta: UIN Sunan Kalijaga.

Riduwan. (2005). Skala Pengukuran Variabel-Variabel Penelitian. Bandung: Alfabeta.

Sadiman, A. S. (2014). Media Pendidikan Pengertian, Pengembangan, dan Pemanfaatannya. Jakarta: PT Rajagrafindo Persada.

Sanaky, H. A. (2009). Media Pembelajaran. Yogyakarta: Safiria Insania Press.

Sugiyono. (2013). Metode Penelitian Pendidikan Pendekatan Kuantitatif, Kualitatif, dan R\&D. Bandung: Penerbit Alfabeta. 
Suhendri, H. (2011). Pengaruh Kecerdasan Matematis-Logis dan Kemandirian Belajar terhadap Hasil Belajar Matematika. Formatif: Jurnal Ilmiah Pendidikan MIPA, 1(1).

Suherman, E. (2006). Pendekatan Kontekstual dalam Pembelajaran Matematika. EDUCARE, 2(1).

Sukmadinata, N. S. (2012). Metode Penelitian Pendidikan. Bandung: PT Remaja Rosdakarya.

Wahyudi. (2017). Strategi Pemecahan Masalah Matematika. Salatiga: Satya Wacana University Press.

Wahyudi, W., Anugraheni, I., \& Winanto, A. (2018). Pengembangan Model Blended Learning Berbasis Proyek Untuk Menunjang Kreatifitas Mahasiswa Merancang Pembelajaran Matematika Sekolah Dasar. JIPM (Jurnal Ilmiah Pendidikan Matematika), 6(2), 68-81.

Wahyuningsih, T., Raharjo, T., \& Masithoh, D. F. (2013). Pembuatan Instrumen Tes Diagnostik Fisika SMA Kelas XI. Jurnal Pendidikan Fisika, 1(1), 111-117.

Wardani, N. S., Slameto, \& Winanto, A. (2012). Asesmen Pembelajaran SD Bahan Belajar Mandiri. Salatiga: Widya Sari Press. 